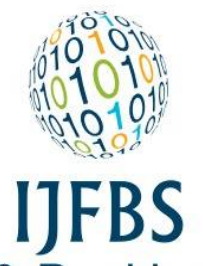

Finance \& Banking Studies

\section{Finans ve Bankacılık Çalışmaları Dergisi}

IJFBS, CILT 5 SAYI 5, Özel Sayı ISSN: 2147-4486

Contents available at www.ssbfnet.com/ojs

Doi: 10.20525/ijfbs.v5i5.636

\title{
Türkiye'de Hayat Dışı Sigortacılık Sektöründe Kârlılık, Sermaye Yapısı ve Yoğunlaşma İlişkisine Yönelik Ampirik Bir Uygulama
}

\section{Veli AKEL}

Doç. Dr., Erciyes Üniversitesi, IïBF, İşletme Bölümü, Kayseri, Türkiye

\section{Talip TORUN}

Yrd. Doç. Dr., Erciyes Üniversitesi, IïBF, İşletme Bölümü, Kayseri, Türkiye

\section{Barış AKSOY}

Öğr. Gör., Cumhuriyet Üniversitesi, IïBF, Bankacılık ve Finans Bölümü, Sivas, Türkiye

\section{Özet}

Bu çalışmanın amacı, Türkiye'de hayat dışı sigortacılık sektöründe aktif karlılığı ile firmaya özgü faktörler arasındaki ilişkiyi tespit ederek aktif kârlılığının etkinlikten mi yoksa yoğunlaşmadan mı kaynaklandığını belirlemektir. Bu amaçla, Türk sigorta sektöründe faaliyet gösteren 36 hayat dışı sigorta şirketi arasında 2015 yılı verilerine göre pazarın toplam \%83.38'ini oluşturan 15 sigorta şirketinin 2010-2015 dönemine ait mali verileri ile performans ilişkisine yönelik Period SUR panel veri analizi yapılmıştır. Analiz sonuçlarına göre, aktif büyüklügü̈, likidite ve pazar payı değişkenleri ile aktif karılı̆̆ı arasında pozitif ve istatistiki olarak anlamlı bir ilişki tespit edilmişken kaldıraç, hasar/prim oranı ve firma yaşı değişkenleri arasında ise negatif ve istatistiki olarak anlamlı bir ilişki tespit edilmiştir. Analiz dönemi boyunca Herfindahl-Hirschman Endeksi değerleri 1.500'ün altında olduğu için Türkiye'de hayat dışı sigortacılık sektörünün yoğun olmayan bir piyasa görünümünde olduğu tespit edilmiştir. Bu nedenle, hayat dışı sigortacılık sektöründe aktif kârılığı yoğunlaşmadan daha ziyade faaliyetlerdeki etkinlikten kaynaklanmaktadır.

Anahtar Kelimeler: Hayat Dışı Sigorta Şirketleri, Aktif Karlıı̆̆ı, Sermaye Yapısı, Yoğunlaşma.

JEL Sınıflandırması: C23, G22. 


\title{
An Empirical Investigation of the Relationship between Profitability, Capital Structure and Concentration in Turkish Non-Life Insurance Industry
}

\begin{abstract}
This paper aims to find the relationship between the return on assets of Turkish non-life insurance industry and the firm-specific factors affecting financial performance and to determine whether return on assets has been emerged from effectiveness or concentration. We employ the Period SUR panel model for the 15 of 36 firms operating in Turkey non-life insurance industry from 2010-2015. Our results clearly show that asset size, liquidity and market share variables have a positive and statistically significant effect on the return assets while leverage ratio, damage/premium ratio and the age of the firms have a negative and statistically significant effect on the return assets. Herfindahl-Hirschman Index belonging to non-life insurance companies used in the study of Turkish non-life index is below 1.500 appears to be less busy market of the insurance market. Therefore, it is derived from that the return on asset of Turkish non-life insurance industry can be linked to efficiency not concentration.
\end{abstract}

Keywords: Non-life Insurance Firms, Return on Assets, Capital Structure, Concentration

JEL Classification: C23, G22.

\section{Giriş}

Sigorta, aynı türden tehlikeyle karşı karşıya olan kişilerin, kurumların prim adı verilen belirli bir miktar para ödemesi ile toplanan fonlarla, yalnızca o tehlikenin gerçekleşmesi sonucu zarara uğrayanların zararını karşılayan ekonomik bir düzenlemedir (Akın ve Ece, 2013:89). Sigortacılığın amacı söz konusu riskleri istatistiksel yöntemlerle belirlemek ve bunların belirli kişi ya da gruplarda yoğunlaşmasını önlemektir. Hayat dışı sigorta yangın, kaza, taşıt sorumluluk gibi risk transferi ile ilgili alanları kapsamaktadır (Knutsen, 1999:69). Hayat dışı sigortacılık son yıllarda varlığını sürdürebilme gayreti içindedir. Bu gelişmenin temel nedeni risk boyutlarındaki değişme ve riskin yoğunluğunun artması olarak değerlendirilebilir.

Sigorta şirketleri topladıkları primlerle fon oluşturarak ve bu fonların tahvil, hisse senedi ve gayrimenkul gibi yatııım araçlarına aktarılması ile ülke ekonomisine önemli bir katkı sağlamaktadırlar. Ayrıca ticaretin devamlıı̆̆ını ve sosyal yapının güçlenmesini sağlayarak ekonomiyi güçlendirmektedirler (Çekici ve İnel, 2013:141). Sigorta şirketlerinin finansal performansı tüm ilgili kesimler (çalışanlar, hissedarlar, potansiyel yatırımcılar, denetim otoriteleri vs.) için büyük öneme sahip olduğundan sigorta şirketlerinin finansal performanslarının ölçümü ve kârlııklarına etki eden unsurların belirlenmesi son dönemde araştırmacıların ilgisini çeken bir konu olmaktadır.

Genel sigorta pazarında ürün ve hizmetler sunan şirketler çok rekabetçi koşullarda çalışmaktadırlar. Pazar gücü firmaların önemli bir zaman dönemi için rekabetçi seviyenin üzerinde fiyatları belirleme yeteneği olarak tanımlanır. Piyasa gücünün varlığının değerlendirilmesi antitröst ve rekabet analizinin önemli bir unsurudur. Rekabetin piyasa bazında yerleşmesi ve işleyiş dinamiğinin devamında devlete büyük görevler düşmekte, devletin bilinçli bir rekabet politikası izlemesi kaçınılmaz olmaktadır. Bu anlamda Amerika Birleşik Devletleri, Avrupa Birliği, Avustralya, Yeni Zelanda ve diğer birçok ülkede hükümet düzenleyicileri birleşme bağlamında ve diğer alanlarda piyasa gücünün değerlendirilmesi konusunda yönergeler yayınlamışlardır (Hausman ve Sıdak, 2007:387). Büyük sigorta şirketlerinin ölçek ekonomileri veya olanaklarından yararlanıp yararlanmadıkları konusu tartışmalıdır. Çünkü, pazar yoğunlaşması, piyasadaki 
bazı firmaların daha etkin çalışması ile büyüyerek pazar paylarını artırmalarından da kaynaklanıyor olabilir (Çelik ve Kaplan, 2007:70).

Bain'in (1951) çalışmasında işbirliği hipotezi ile ileri sürdüğü görüşe göre, piyasa yoğunlaşmasının kârlılık ile arasında doğrusal, piyasa yoğunlaşmasının piyasa performansı ile arasında ise ters yönlü bir ilişki söz konusudur. Başka bir ifadeyle, yoğunlaşmanın fazla olduğu piyasalarda yoğunlaşmaya neden olan firmaların azalan maliyetler ve yüksek kâr nedeniyle etkin olmayacakları ve bu piyasada rekabet düzeyinin de düşük olacağı varsayılmaktadır (Bain, 1951:294). Bain'in ileri sürdüğü hipotezin tersi Demsetz (1973) tarafından ileri sürülmüştür. Demsetz, piyasadaki yoğunlaşmanın, bazı firmaların daha etkin çalışması sonucu büyüyerek piyasa paylarını artırmalarından kaynaklanıyor olabileceğine işaret etmektedir. Demsetz'e göre bu durumda yoğunlaşma, rekabetin bir sonucu olarak ortaya çıkmaktadır. Kârlılığın yoğunlaşmadan mı yoksa etkinlikten mi kaynaklandığı sorusuna cevap vermek ülkelerin uygulayacakları rekabet politikaları açısından önemlidir. Bunun nedeni yüksek kârlılık eksik rekabetten kaynaklanıyor ise eksik rekabet piyasasını değiştirmek için atılacak adımlar etkinlik ve verimliliği artıracaktır. Diğer taraftan yüksek kârııı̆ın nedeni etkin ve verimli çalışma ise o zaman piyasaya müdahaleye gerek kalmayacaktır (Demsetz, 1973:2).

Literatür incelemesinde firmaların sermaye yapısının kârlılık üzerindeki etkisini ölçen yurt dışında yapılmış çok sayıda çalışma bulunmaktadır. Ancak, Türk hayat dışı sigorta sektöründe finansal performans üzerinde etkiye sahip olan firma içi faktörler ile performans arasındaki ilişkinin belirlenmesi ve mali performansın bir göstergesi olan aktif kârlıı̆̆ının etkinlikten mi yoksa yoğunlaşmadan mı kaynaklandığı konusunu bir arada değerlendiren çalışma ise yok denecek kadar azdır. Dolayısıyla bu çalışmada, bir yandan sigorta şirketlerinin sermaye yapısı ve aktif kârııı̆ı ilişkisi incelenirken diğer yandan da aktif kârıı̆ı̆ının etkinlikten mi yoksa sektördeki yoğunlaşmadan mı kaynaklandığına ilişkin analizler çalışmamızın özgün yönünü oluşturmaktadır. Çalışma 3 bölümden oluşmaktadır. Birinci bölümde, sigortacılık sektörünün karlılığı üzerine literatür taraması yapıldıktan sonra ikinci bölümde model ve veri seti tartışılarak üçüncü bölümde ise araştırma bulgularına yer verilmiştir.

\section{Literatür İncelemesi}

Endüstri iktisadında kârııık ve yoğunlaşma arasındaki ilişki iki paradigma yardımıyla incelenebilmektedir. Bunlar; "yapı-davranış-performans" paradigması ve "etkin yapı" paradigmasıdır (Özcan ve Çiftçi, 2015:3). 1940'larda Mason tarafından Harvard Üniversite'sinde başlatılan "yapı-davranış-performans" paradigmasının ampirik çalışmaları ilk kez Bain (1951) tarafından yapıımışıı. Bu yaklaşıma göre bir sektörün performansı, pazarın yapısına bağlı olarak alıcı ve satıcıların davranışlarına bağlıdır. Dolayısıyla pazar yapısı, davranış ve performansın tahmin edilmesinde kullanılabilir (Rekabet Kurumu, 2014: 199). Bain'e göre yoğunlaşma işbirliği maliyetlerini azaltarak firmalar arası işbirliğini kolaylaştırmaktadır. Bu işbirliği sayesinde de firmalar normalüstü karlar elde edebilmektedir. Yoğunlaşmanın kârlıı̆̆ı artırdığını öne süren bu yaklaşımın aksine Demsetz (1973) firma performansının yüksek olmasının bir sonucu olarak piyasanın kendiliğinden yoğunlaşacağını savunmaktadır. "Etkin yapı" paradigması olarak bilinen bu yaklaşıma göre kârlıık yoğunlaşmayı artırmaktadır.

Gerek reel sektörde gerekse finans sektöründe kârlılık ve yoğunlaşma arasındaki ilişkinin araştııılığı pek çok çalışma bulunmaktadır. Finans sektöründeki çalışmaların önemli bir kısmı bankacılık sektöründe yapılmıştır. Smirlock (1985), Civelek ve Alami (1991), Goldberg ve Rai (1996), Günalp ve Çelik (2004), Abbasoğlu, Aysan ve Güneş (2007), Shahiki Tash, Pahlavani ve Barghandan (2015), Hakimi, Hamdi ve Djelassi (2015), Özcan ve Çiftçi (2015) bankacılık sektörü üzerinde yapılan çalışmalardan bazılarıdır.

Finans sektöründe bankaların yanı sıra sigorta şirketleri de önemli bir yere sahiptir. Ancak sigortacılık sektörü üzerinde kârııık ve yoğunlaşma arasındaki ilişkiyi araştıran sınırlı sayıda çalışma mevcuttur. Bu çalışmalar aşağıda kısaca anlatılmaktadır.

Çelik ve Kaplan (2007), Türk sigortacılık sektöründe elemanter alanda faaliyet gösteren 25 sigorta şirketine ait 2002-2004 dönemi verilerini kullanarak yoğunlaşma ve kârlıık arasındaki ilişkiyi araştırmışlardır. "Yapıdavranış-performans" paradigması çerçevesinde yapılan analiz sonuçlarına göre sektörde yoğunlaşma ile 
kârlııı arasında güçlü ve doğrusal bir ilişkinin bulunduğu tespit edilmiştir. Bu bulgulardan hareketle ilgili dönemde sektörün eksik rekabetçi bir yapıya sahip olduğu sonucuna ulaşıımıştır.

Pope ve Ma (2008), uluslararası hayat dışı sigorta sektöründe "yapı-davranış-performans" hipotezinin uygulanabilirliğini test etmişlerdir. 1996-2003 dönemi için 23 gelişmiş ve gelişmekte olan ülkeyi kapsayan çalışmada piyasanın serbestleşmesi ve yoğunlaşma etkileşimiyle kârlılık arasında kompleks bir ilişki olduğu sonucu ortaya çıkmıştır. Çalışmanın bulguları piyasanın serbestleşme derecesi düşük olduğunda "yapıdavranış-performans" hipotezinin öne sürdüğü beklentileri desteklemektedir.

Berry-Stolzle, Weiss ve Wende (2011), Avrupa'daki 12 ülkenin 2003-2007 dönemi verilerini kullanarak sigorta sektöründe "yapı-davranış-performans" hipotezini "göreli pazar gücü" hipotezini ve "etkin yapı" hipotezini test etmişlerdir. Çalışmanın sonuçları güçlü şekilde "etkin yapı" hipotezini desteklemektedir. Bulgular "göreli pazar gücü" hipotezini desteklerken "yapı-davranış-performans" hipotezi için destek sağlamamaktadır.

Njegomir ve Stojić (2011), Doğu Avrupa ülkelerindeki hayat dışı sigorta sektörü için "yapı-davranışperformans" hipotezini sınamışlardır. Çalışma, 11 ülkenin 2004-2008 dönemi verilerini kapsamaktadır. Sonuçlar, piyasa yapısı ve serbestleşmenin kârlılık üzerinde güçlü etkisi olduğuna kanıt sağlayan gözlenen modellerin tümünde "yapı-davranış-performans" hipotezini desteklemektedir.

Njegomir, Stojić ve Marković (2011), yukarıdakine benzer bir çalışmayı Eski Yugoslavya bölgesindeki hayat dışı sigorta sektörü için de yapmışlardır. Çalışmanın amacı piyasa yapısı, serbestleşme ve performans arasındaki ilişkiyi araştırmaktır. Çalışmada, 2004-2008 dönemi için eski Yugoslavya bölgesindeki 5 ülkeyi kapsayan bir panel veri analizi uygulanmıştır. Elde edilen sonuçlar "yapı-davranış-performans" hipotezini desteklemektedir. Çalışmada, serbestleşmedeki artışın yoğunlaşmayı ve dolaylı olarak da kârlılığı azaltacağı öne sürülmektedir.

İşletme finansmanında, sermaye yapısı kararları hayati bir öneme sahiptir. Çünkü söz konusu kararların kârlııık üzerinde doğrudan etkisi olduğu düşünülmektedir. Literatürde reel sektör işletmeleri üzerinde sermaye yapısı ve kârlıık arasındaki ilişkiyi araştıran çok sayıda çalışma mevcuttur. Sermaye yapısı ile kârlııı arasındaki ilişki reel sektör işletmelerine benzer şekilde finans sektöründeki işletmeler için de son derece önemlidir. Bu nedenle literatürde ağırlık her ne kadar bankalar üzerinde olsa da gerek diğer ülkelerde gerekse Türkiye'de sigorta sektörü için yapılmış çalışmalar da bulunmaktadır. Ayrıca tüm işletmelerde olduğu gibi sigorta sektöründe de finansal performansın değerlendirilmesi ve performansı etkileyen faktörlerin ortaya konulması önemli bir araşııma alanıdır. Bu çalışmaların da önemli bir kısmında sermaye yapısının performansı etkileyen faktörlerden biri olduğu ortaya konulmuştur.

Chen vd. (2009), sermaye yapısı ve operasyonel riskin kârlılık üzerindeki etkilerini tespit edebilmek amacıyla 1993-2003 dönemi için Tayvan hayat sigortası sektörünü incelemişlerdir. Bulgular kaldıracın (varlık finansmanında yabancı kaynak kullanımı) kârlııı üzerinde negatif bir etkiye sahip olduğunu göstermektedir. Bu sonuç sigorta şirketlerinde toplam kaynaklar içerisinde öz kaynakların payı arttığında şirketin daha yüksek kârlılığa sahip olacağı anlamına gelmektedir.

Malik (2011), Pakistan'da 35 hayat ve hayat dışı sigorta şirketinin 2005-2009 dönemi verilerini analiz etmiş ve bazı değişkenlerin kârlııkla ilişkisini araştırmıştır. Aktif kârlıı̆ının bağımlı değişken olarak kullanıldığı çalışmada firma büyüklüğü ve sermaye hacmi ile kârııık arasında pozitif; kayıp oranı ve kaldıraç ile kârlııı arasında ise negatif bir ilişki olduğu tespit edilmiştir. Ayrıca şirketin yaşı ile kârııık arasında bir ilişki bulunamamıştır. Kaldıraçla kârılık arasında istatistiksel olarak anlamlı ancak negatif bir ilişki bulunmuştur. Pakistan'da yapılan diğer bir çalışma da 2007-2013 dönemi için Pakistan'daki beş hayat sigortası şirketinin verileri üzerinde sermaye yapısı kararlarına ilişkin yapılan Rahman, Kakakhel ve Iqbal (2014) ün çalışmasıdır. Firma büyüklüğü, yaşı, kârııı̆ı gibi faktörlerin sigorta sektörünün sermaye yapısı üzerindeki etkisinin araştırıldığı çalışmanın sonucunda kârlılıkla kaldıraç arasında negatif bir ilişki olduğu tespit edilmiştir.

Pervan vd. (2012), Bosna-Hersek'te bulunan sigorta şirketlerinin 2005-2010 döneminde kârlılığını etkileyen faktörleri araştırmışlardır. Yapılan dinamik veri analizinde yaş, pazar payı ve geçmiş dönem performansının 
kârlıık üzerindeki etkisinin anlamlı ve pozitif olduğu, hasar prim oranıyla karlıık arasında ise anlamlı fakat negatif bir ilişki bulunduğu sonucuna ulaşılmıştır.

Akotey vd. (2013), gelişmekte olan bir ekonomi olarak Gana'da hayat sigortası sektörünün finansal performansını değerlendirmek amacıyla bir çalışma yapmışlardır. Gana hayat sigortası sektöründe 17 şirketin 11 yılı (2000-2010) kapsayan verileri üzerinde kârııı̆ın ana belirleyicileri araştııılmıştır. Çok sayıda açıklayıcı değişkenin ele alındığı çalışmada sermaye yapısına ilişkin olarak kaldıraçla kârılık (kullanılan dört kârlııı ölçüsünden üçü) arasında pozitif bir ilişki saptanmıştır. Bu durum sigorta şirketlerinin yabancı kaynakları kârlı varlıklara dönüştürebilme yeteneğinin bir göstergesi olarak yorumlanmaktadır. Gana'da sigorta sektöründe kârlıı̆ı̆ belirleyicilerini araştıran bir diğer çalışma da Boadi, Antwi ve Lartey (2013) dir. 16 sigorta şirketinin 2005-2010 dönemi verileri üzerinde yapılan bu çalışmada maddi duran varlıkların toplam varlıklar içerisindeki payı ile kârlıık arasında negatif; kaldıraç ve likidite ile kârlıık arasında ise pozitif bir ilişki tespit edilmiştir.

Tornyeva (2013), Gana'daki 12 sigorta şirketinin 2002-2007 dönemi verilerini kullanarak sermaye yapısını belirleyen faktörleri araştırmıştır. Çalışmanın sonucunda, kârlıık ve kaldıraç arasında negatif bir ilişki olduğu tespit edilmiş ve bu durumun kârlı sigorta şirketlerinin iç finans kaynaklarını dış kaynaklara tercih etmesinden kaynaklandığı ileri sürülmüştür.

Doğan (2013), Borsa İstanbul'da faaliyet gösteren sigorta şirketlerinin 2005-2011 dönemi verilerini kullanarak sermaye yapısının kârlılık üzerindeki etkisini araştırmıştır. Kârılık göstergesi olarak aktif kârlıı̆ıııı kullanıldığı araştırmada; aktif büyüklüğü ile kârııık arasında pozitif yönlü, kaldıraç (borç/öz kaynak), kısa vadeli borç ödeme yeteneği, hasar pirim oranı ve şirketin yaşı ile kârlılık arasında ise negatif yönlü bir ilişki tespit edilmiştir. Bu çalışmaya göre sermaye yapısı içerisinde borçların payının artması kârlıı̆ı azaltmaktadır.

Elitaş ve Doğan (2013), 2005-2011 dönemi için Borsa İstanbul'da faaliyet gösteren sigorta şirketlerinin sermaye yapısını belirleyen faktörleri ortaya koymak amacıyla bir çalışma yapmışlardır. Bağımlı değişken olarak kaldıraç oranının kullanıldığı araşıımanın sonucunda kârlılık ile kaldıraç oranı arasında pozitif yönde bir ilişki tespit edilmiştir.

Kaya ve Kaya (2015), hayat sigortası şirketlerinde finansal performansı etkileyen firmaya özgü faktörleri belirlemek amacıyla bir çalışma yapmışlardır. 17 hayat sigortası şirketinin 2008-2013 dönemi verilerinden oluşan bir panel veri seti oluşturularak yapılan araştırmada finansal performans ölçüsü olarak aktif kârlılı̆ı kullanılmışıır. Sonuçlar brüt primlerin ve şirket yaşının kârlılık üzerinde olumlu, buna karşılık şirket büyüklüğü, cari oran ve sigorta kaldıraç oranının kârlılık üzerinde olumsuz etkisi olduğunu göstermektedir.

Çekrezi (2015), Arnavutluk'taki beş sigorta şirketinin 2008-2013 dönemi verilerini incelemiştir. Sonuçlar, kaldıracın ve riskin (satışların standart sapması) aktif kârııı̆ı üzerinde negatif bir etkiye sahip olduğunu; maddi duran varlıkların toplam varlıklara oranının ise kârlıık üzerinde pozitif bir etkiye sahip olduğunu göstermektedir.

Mwangi ve Murigu (2015), Kenya'da gayri safi yurtiçi hasılaya \%2.08 katkı sağlayan sigorta sektörünün 2009-2012 dönemi verileri üzerinde finansal performansı belirleyen faktörleri araştırmışlardır. Çalışmada kaldıraç oranı, öz kaynakların logaritması ve yönetim kapasitesi ile kârılık arasında pozitif yönlü; firma büyüklüğü ve yabancı ortak sayısı ile kârlılık arasında ise negatif yönlü bir ilişki olduğu sonucuna ulaşılmıştır.

\section{Araştırma ve Yöntem}

\section{Veri Seti}

Türkiye'de sigorta sektöründe faaliyet gösteren 36 hayat dışı sigorta şirketi arasında 2015 yılı 10 aylık verilere göre prim büyüklüğü bakımından toplam \% 83.38 pazar payına sahip 15 sigorta şirketinin 2010/Q12015/Q3 dönemi olmak üzere toplam 23 çeyrek dönem finansal verileri ile performans ve yoğunlaşma ilişkisine yönelik panel veri analizi yapılmıştır. 2010-2015 dönemine ait veriler, Türkiye Sigorta Birliği ile 
Borsa İstanbul (BIST)'un web sayfalarından ve araştırmaya konu olan şirketlerin internet sitelerinden elde edilmiştir. Analiz dönemi boyunca pazar payı en yüksek olan sigorta şirketleri Tablo 1'de gösterilmiştir.

Tablo 1: Analiz Kapsamında Yer Alan Sigorta Şirketleri ve Pazar Payları (\%)

\begin{tabular}{|c|l|r|r|r|r|r|r|}
\hline Sıra & Şirket Adı & $\mathbf{2 0 1 0 / 1 2}$ & $\mathbf{2 0 1 1 / 1 2}$ & $\mathbf{2 0 1 2 / 1 2}$ & $\mathbf{2 0 1 3 / 1 1}$ & $\mathbf{2 0 1 4 / 1 1}$ & $\mathbf{2 0 1 5 / 1 0}$ \\
\hline 1 & Allianz Sigorta A.Ş. $^{1}$ & 14.70 & 14.52 & 15.61 & 15.60 & 14.24 & 14.63 \\
\hline 2 & Anadolu Anonim Türk Sig. A.Ş. & 11.89 & 13.30 & 13.06 & 12.71 & 13.13 & 13.28 \\
\hline 3 & Axa Sigorta A.Ş. & 12.71 & 13.80 & 13.94 & 15.20 & 13.37 & 11.14 \\
\hline 4 & Mapfre Genel Sigorta A.Ş. & 3.45 & 3.85 & 5.18 & 6.67 & 6.64 & 7.42 \\
\hline 5 & Aksigorta A.Ş. & 7.42 & 7.85 & 7.66 & 7.50 & 7.79 & 6.23 \\
\hline 6 & Groupama Sigorta A.Ş. & 5.81 & 5.65 & 4.83 & 4.79 & 4.76 & 4.56 \\
\hline 7 & Güneş Sigorta A.Ş. & 6.17 & 5.66 & 5.39 & 4.78 & 5.14 & 4.55 \\
\hline 8 & Ziraat Sigorta A.Ş. & 1.44 & 2.20 & 2.21 & 2.82 & 3.15 & 3.66 \\
\hline 9 & Eureko Sigorta A.Ş. & 5.18 & 4.90 & 4.00 & 3.83 & 3.48 & 3.61 \\
\hline 10 & Sompo Japan Sigorta A.Ş. & 2.67 & 2.28 & 2.63 & 2.67 & 3.03 & 3.59 \\
\hline 11 & Ergo Sigorta A.Ş. & 5.81 & 4.83 & 3.99 & 2.71 & 2.96 & 3.34 \\
\hline 12 & Halk Sigorta A.Ş. & 1.30 & 1.43 & 2.31 & 2.28 & 2.43 & 2.84 \\
\hline 13 & HDI Sigorta A.Ş. & 1.87 & 1.99 & 2.33 & 2.29 & 2.57 & 2.62 \\
\hline 14 & Neova Sigorta A.Ş. & 1.94 & 0.59 & 0.77 & 1.24 & 1.67 & 1.91 \\
\hline 15 & Zurich Sigorta A.Ş. & 2.18 & 2.00 & 1.78 & 1.86 & 1.83 \\
\hline
\end{tabular}

Çalışma kapsamındaki hayat dışı sigorta sektöründe faaliyet gösteren 15 şirketin yalnızca üçü BIST'de işlem görmektedir. Diğer 12 şirketin 23 dönemlik mali verileri, ilgili şirketlerin internet sitelerinden elde edilmiş, internet sitelerinde bulunmayan dönemlere ait veriler ise ilgili şirketlerden mail ve telefon görüşmesi vasıtasıyla talepte bulunularak elde edilmiştir. Tüm sektörü temsilen sigorta şirketlerinin mali verilerine ulaşılabilen resmi bir kaynak bulunmamaktadır. Türk hayat dışı sigorta sektöründe faaliyet gösteren şirket sayısının fazla olmasına rağmen tüm şirketlerin mali tablolarına ulaşılabilmesindeki güçlük nedeniyle veri seti, 15 hayat dışı sigorta şirketinin 23 çeyrek dönemlik verisi ile sınırlandııımıştır.

Sigorta şirketlerinin finansal performansını etkileyen faktörler şirketlerin hayat dışı veya hayat sigortacılığı alanında faaliyet göstermesine göre farklııık gösterebilir. Analizde kullanılan bağımlı ve bağımsız değişkenler ilgili teori ve literatürde yer alan (Örneğin; Doğan (2013), Çelik ve Kaplan (2007), Kaya ve Kaya (2015), Malik (2011) Mehari ve Aemiro (2013)) çalışmalara dayanılarak seçilmiştir. Sigorta şirketlerinin finansal performansını etkileyen faktörler, firmaya özgü faktörler ve dış faktörler olmak üzere iki gruba ayrılmaktadır. Bu çalışmada ise sadece firmaya özgü faktörler kullanılmışıı. Analizde bağımlı değişken olarak aktif kârlıı̆ı, bağımsız değişkenler olarak aktif büyüklüğü, kaldıraç, likidite, hasar/prim, pazar payı ve faaliyet süresi kullanılmıştır. Çalışmada kullanılan değişkenlerin hesaplanması ve bu değişkenlerin bağımlı değişken üzerindeki beklenen etkileri ise Tablo 2'de verilmiştir.

\footnotetext{
${ }^{1} 2014$ yılında Yapı Kredi Sigorta ve Allianz Sigorta A.Ş. birleşmiştir.
} 
Tablo 2: Değişkenlerin Hesaplanması ve Bağımlı Değişken Üzerindeki Beklenen Etkileri

\begin{tabular}{|c|l|l|c|}
\hline Bağımlı Değişken & Değişkenler & Hesaplama & $\begin{array}{c}\text { Bağımsız } \\
\text { Değişkenlerin Aktif } \\
\text { Karlılığı Üzerine } \\
\text { Beklenen Etkisi }\end{array}$ \\
\hline Bağın) & $\begin{array}{l}\text { Vergi Öncesi Net Kâr / } \\
\text { Toplam Varlık }\end{array}$ & Negatif / Pozitif \\
\hline & Aktif Büyüklüğü (LAKT) & Toplam Varlıklar & Negatif / Pozitif \\
\cline { 2 - 3 } & $\begin{array}{l}\text { Kaldıraç } \\
\text { (KAL) }\end{array}$ & Toplam Borç / Özsermaye & Negatif \\
\cline { 2 - 3 } & $\begin{array}{l}\text { Likidite- Cari Oran } \\
\text { (LIKID) }\end{array}$ & $\begin{array}{l}\text { Cari Varlıklar / Kısa Vadeli } \\
\text { Yükümlülükler }\end{array}$ & Negatif \\
\cline { 2 - 3 } & $\begin{array}{l}\text { Hasar/Prim Oranı } \\
\text { (HASP) }\end{array}$ & $\begin{array}{l}\text { Net Gerçekleşen Hasar / } \\
\text { Net Kazanılmış Prim }\end{array}$ & Pozitif \\
\cline { 2 - 3 } & $\begin{array}{l}\text { Pazar payı } \\
\text { (PAZP) }\end{array}$ & $\begin{array}{l}\text { Sigorta Şirketlerinin Pazar } \\
\text { Payı }\end{array}$ & Pozitif \\
\hline & $\begin{array}{l}\text { Faaliyet Süresi } \\
\text { (YAS) }\end{array}$ & 2015-Kuruluş Yılı & \\
\hline
\end{tabular}

Tablo 2'de yer alan ve çalışmada kullanılan bağımsız değişkenlere ilişkin bazı açıklamalarda bulunmak faydalı olacaktır.

Aktif Büyüklüğü (LAKT): Bir sigorta şirketinin yükümlülüklerini karşılamaya yetecek kadar aktifinin bulunması durumunda mali yeterliliğinin olduğu kabul edilmektedir (Şenel, 2006: 299). Kaya ve Kaya (2015), Mehari ve Aemiro (2013), Almajali vd. (2012) tarafından yapılan çalışmalarda görüleceği üzere firma büyüklüğünün, firma performansı üzerine etkisi açık değildir ve halen tartışımaktadır. Çünkü büyük firmalar ölçek ekonomisinden yararlandıklarından küçük firmalara göre daha etkili olabilmektedir. Diğer taraftan firmalar daha büyük hale geldiklerinde mali verimsizlik ve performans düşmesi riski ile karşı karşıya kalabilirler. Bu nedenle aktif büyüklüğü ile finansal performans arasındaki ilişki ile ilgili belirli bir yönde beklentimiz bulunmamaktadır. Aktif büyüklüğü değişkeni değer olarak alındığından bu değerlerdeki aşırıı̆̆ı ortadan kaldırmak amacıyla aktif toplamının doğal logaritması alınmıştır.

Kaldıraç (KALD):Yüksek kaldıraca sahip firmalar riskli sayılabilirken aynı zamanda bu firmaların borçlarını geri ödemesi ve yeni krediler temin etmesi her zaman mümkün olmayabilecektir. Diğer taraftan yüksek kaldıraca olumsuz bir durum olarak bakılabilirken, borç-yatıım ilişkisi, firmaların kârlıığını olumlu yönde de etkileyebilir. Literatürde kaldıracın aktif kârııı̆ı üzerinde olumsuz etkisinin olduğu yönünde ((Malik (2011), Doğan (2013)) bulgular varken olumlu olduğu yönünde de (Mehari ve Aemiro (2013), Almajali vd. (2012)) sonuçlar bulunmaktadır. Bu nedenle aktif kârlılığı ile kaldıraç arasında belirli yönde bir beklentimiz bulunmamaktadır.

Likidite (LIKID): Şirketlerin kısa vadeli borçlarını ödeme güçlerini ölçmek amacıyla literatürde sıkça kullanılan (Doğan (2013), Kaya ve Kaya, (2015)) ve kolay hesaplanması nedeniyle hayat dışı sigorta şirketlerinin likidite ölçüsü olarak bu çalışmada cari oran kullanılmıştır. Oran; sigorta şirketlerinin çalışma sermayesinin yeterli olup olmadığını başka bir deyişle varlıklarını nakde dönüştürme yeteneğini gösterir. Likidite oranının artmasına bağlı olarak likidite riski azalmakta ancak aktif kârlıı̆̆ı bundan olumsuz etkileneceği için likidite ve aktif kârııı̆̆ı arasında negatif ilişki beklenmektedir.

H1: Türk hayat dışı sigorta sektöründe en fazla pazar payına sahip 15 şirketin likidite oranları ile kârıııkları arasında negatif bir ilişki vardır.

Hasar/Prim (HASP): Literatürde yüklenim riski ya da kayıp oranı olarak ifade edilen ve gerçekleşen hasarın kazanılan prime oranını temsil eden bu gösterge, şirketlerin risk seçimindeki performanslarını gösteren en önemli göstergelerden birisidir. Şirketlerin belirlediği primlerin, poliçede verilen teminatların kapsamına giren risklerin gerçekleşmesi sonucu ortaya çıkan hasarı karşılamaya yetip yetmediğini ifade eden bu oran ne kadar düşük olursa o kadar iyidir (Doğan, 2013:126). 
H2: Türk hayat dışı sigorta sektöründe en fazla pazar payına sahip 15 şirketin hasar prim oranı ile kârıııkları arasında negatif bir ilişki vardır.

Pazar Payı (PAZP): Toplam prim üretimine göre Türk hayat dışı sigorta sektöründeki on beş büyük firmanın pazar paylarından oluşmakta ve piyasadaki yoğunlaşmayı temsil etmektedir (Çelik ve Kaplan, 2007:77).

H3: Türkiye'de hayat dışı sigorta sektöründe en fazla pazar payına sahip 15 şirketin pazar payı ile kârlııkları arasında pozitif bir ilişki vardır.

Faaliyet Süresi (YAS) : Şirket yaşı hayat dışı sigorta şirketlerinin Türk sigorta sektöründe faaliyette bulunduğu yıl sayısını göstermektedir. Performans ve kârııık ölçümünde faaliyet süresi bağımsız değişken olarak bazı çalışmalarda (Mehari ve Aemiro, 2013) kullanılmıştır. Yeni kurulmuş ve belirli bir ölçek büyüklüğüne ulaşamamış firmalar marka imajı, sermaye yeterliliği ve itibar konularında bir takım olumsuzluklara sahip olabilir. Ancak köklü firmaların daha fazla kâr edeceğine yönelik de kesin bir bulguya rastlanmamaktadır. Bu konu literatürde tartışmalı olmakla beraber bulgular ağırıklı olarak faaliyet süresi ile kârlııı arasında pozitif ilişki bulunduğunu gösterdiğinden çalışmamızda da bu beklenti esas alınmışır.

H4: Türkiye'de hayat dışı sigorta sektöründeki şirketlerin faaliyet süreleri ile kârlııkları arasında pozitif bir ilişki vardır.

\section{Araştırmanın Yöntemi}

Karma verilerde yatay kesit birimleri değişmiyorsa, veriler aynı yatay kesit birimlerinde zamana göre değişim gösteriyorsa bu tür karma veriye panel veri adı verilmektedir. Panel veri kullanmanın çeşitli yararları bulunmaktadır. İlki, örneklem büyüklüğünü ciddi oranda artırır. İkincisi, tekrarlanan kesit gözlemlerinin incelenmesiyle değişim hareketleri daha iyi incelenir. Üçüncüsü ise daha karmaşık modellerin rahatlıkla incelenmesi olanağını sunar (Gujarati ve Porter, 2012:612). Bunların dışında, kurulan modellerde gözlem sayısının geleneksel yöntemlere göre daha fazla olması ile elde edilecek parametre tahminleri daha güvenilir hale gelmektedir. Bu da daha karmaşık davranış modellerinin kurulmasına ve test edilmesine olanak vermekte, model dışında tutulan değişken veya değişkenlerin birimlere veya zamana göre değişmeyen değişkenler olması durumunda olası sapmalar kontrol altına alınmaktadır. Ayrıca birimler ve bir birimin içerisinde zamana göre meydana gelen farklııkların birlikte incelenebilmesine olanak vermesi gibi üstünlükleri söz konusudur. Sıralanan bu üstünlükler, veri setlerinin yetersiz olduğu sigortacılık alanında panel veri yöntemini etkin bir analiz aracı haline getirmektedir.

Yukarıda kısaca izah edilmeye çalışılan nedenlerden dolayı bu çalışmada ekonometrik analiz tekniği olarak panel veri yöntemi tercih edilmiş olup aşağıdaki ekonometrik model tahmin edilmeye çalışılmıştır.

$A K A R_{i t}=\alpha_{i t} \beta_{1} L A K T_{i t}+\beta_{2} K A L D_{i t}+\beta_{3} L I K I D_{i t}+\beta_{4} H A S P_{i t}+\beta_{5 \Delta} P A Z P_{i t}+\beta_{6} Y A S_{i t}+e_{i t}$

(1) nolu denklemde;

$A K A R_{\text {it }}$ : Aktif kârlıı̆ını,

$L A K T_{\text {it }}:$ Aktif büyüklüğünün logaritmasını,

$K A L D_{\text {it }}:$ Kaldıraç oranını,

LIKID ${ }_{\text {it }}$ : Likidite oranını,

$H A S P_{i t}$ : Hasar/Prim oranını,

$P A Z P_{i t}:$ Her bir sigorta şirketinin pazar payını,

$Y A S_{i t} \quad$ : Sigorta şirketlerinin faaliyet süresini göstermektedir.

Sabit etkiler modeli ve rassal etkiler modeli olmak üzere iki temel yaklaşımın söz konusu olduğu $K$ değişkenli panel veri modeli genel olarak; 


$$
y_{i t}=\beta_{1 i t}+\beta_{2 i t} X_{2 i t}+\ldots \ldots \ldots \beta_{K i t} X_{K i t}+\varepsilon_{i t}
$$

şeklinde gösterilebilir. Rassal etkiler modelinde yatay kesit birimlerindeki farklılıkların hata terimi gibi rassal olduğu varsayılmaktadır. Sabit etkiler modelinde eğim katsayıları zaman ve kesit birimleri için aynı olup sabit katsayı ise yatay kesit birimlerine göre değişmektedir. Bu modelde yatay kesit birimleri arasındaki farklar sabit terimdeki farklııklarla açıklanmakta ve panel veri modeli kukla değişken yardımıyla tahmin edilmektedir (Brooks, 2008:490-491).

Ayrıca, Türkiye'de hayat dışı sigortacılık sektörünün yoğunlaşma derecesini ölçerek sektörün rekabet yapısı hakkında bazı çıkarımlarda bulunmaya çalışımışır. Literatürde, incelenen sektörün yoğunlaşma derecesini ölçmek üzere farklı endeksler kullanılmaktadır. Kullanılan endekslerden en sık kullanılanları ise M-Firma Yoğunlaşma Oranı ile Herfindahl-Hirschman Endeksi (HHI) yöntemleridir. M-Firma Yoğunlaşma Oranı, piyasa yoğunlaşmasını piyasada belirli ürünlerde faaliyet gösteren genellikle en büyük dört, sekiz veya on iki firmanın paylarının toplamı şeklinde ifade eder. HHI, 1970 ve 1980'ler boyunca sektördeki yoğunlaşma ve piyasa rekabeti çalışmalarında kullanılmış bir yöntem olup en büyük 4 firmanın pazar paylarının dağılımını yansıtmanın yanı sıra tüm pazarın durumunu da yansıtmaktadır. HHI, en basit ifadeyle, piyasadaki her bir firmanın pazar paylarının karelerinin toplamı olup aşağıdaki gibi hesaplanmaktadır (Calkins, 1983:407):

$$
H H I=S_{1}^{2}+S_{2}^{2}+\ldots+S_{n}^{2}=\sum_{i=1}^{n} S_{i}^{2}
$$

(3) nolu denkleme göre, HHI; 0 (Tam rekabet) ve 10.000 (Monopol) arasında değerler almaktadır. Piyasalar, yoğunlaşmaları bakımından 3 kısımda incelenmektedir. Bunlar; i) Yoğun olmayan piyasalar: HHI değeri 1.500 den az olan piyasalar, ii) Az yoğun piyasalar: HHI değeri 1.500-2.500 arası piyasalar, iii) Çok yoğun piyasalar: HHI değeri 2.500 den fazla olan piyasalardır (Roberts, 2014:912).

\section{Bulgular}

Analiz uygulamasından önce değişkenlere ait tanımlayıcı istatistiklerin incelenmesinde fayda vardır. 2010/Q1-2015/Q3 dönemini kapsayan panel veri analizinde kullanılan bağımlı ve bağımsız değişkenlere ait tanımlayıcı istatistikler Tablo 3'de sunulmuştur. Tablo 3 incelendiğinde aktif kârlıık oranının -0.34 ile 0.21 arasında değişkenlik gösterdiği, ortalamasının 0.006 ve standart sapmasının ise 0.058 olduğu görülmektedir. Cari oranı temsil eden LIKID değişkeninin ortalaması ise 1,348 olup hem kısa vadeli borçları ödeme gücü yönünden yeterli olarak görülmekte hem de cari varlıklarda fazla tutar bulundurulmaması sonucu kârlııık olumlu etkilenebilecektir. Kaldıraç oranı ortalaması 2.583 ile literatürdeki bazı çalışmalar ile (Kaya ve Kaya (2015)) uyumludur. Araştırma kapsamındaki sigorta şirketlerinin hasar/prim oranının 0.636 ortalama ile net gerçekleşen hasarların net kazanılmış primlerden daha az olduğu görülmektedir. Ayrıca değişkenlerin hiç biri normal dağılım göstermemektedir.

Tablo 3: Değişkenlere Ait Tanımlayıcı İstatistikler

\begin{tabular}{|lrrrrrrr|}
\hline & AKAR & LAKT & KALD & LIKID & HASP & PAZP & YAS \\
\hline Ortalama & 0.006 & 20.500 & 2.583 & 1.348 & 0.636 & 5.667 & 62.325 \\
Ortanca & 0.012 & 20.580 & 2.360 & 1.340 & 0.660 & 4.000 & 56.000 \\
En Yüksek & 0.210 & 22.312 & 8.800 & 2.900 & 1.440 & 15.610 & 143.000 \\
En Düşük & -0.340 & 17.315 & 0.490 & 0.070 & 0.140 & 0.520 & 1.000 \\
Std. Sapma & 0.058 & 0.930 & 1.100 & 0.244 & 0.161 & 4.436 & 41.366 \\
Çarpıklık & -1.457 & -0.584 & 1.573 & 0.667 & -0.242 & 1.037 & 0.143 \\
Basıklık & 10.269 & 3.468 & 7.658 & 10.204 & 4.670 & 2.711 & 1.943 \\
Jarque-Bera & 881.742 & 22.779 & 454.133 & 771.715 & 43.445 & 63.001 & 17.217 \\
p -Değeri & 0.000 & 0.000 & 0.000 & 0.000 & 0.000 & 0.000 & 0.002 \\
n & 345 & 345 & 345 & 345 & 345 & 345 & 345 \\
\hline
\end{tabular}


Tablo 4'de ise değişkenler arasındaki korelasyon katsayılarını görmek mümkündür.

Tablo 4: Değişkenler Arasındaki Korelasyon Katsayıları

\begin{tabular}{|l|rrrrrrr|}
\hline & AKAR & LAKT & KALD & LIKID & HASP & PAZP & YAS \\
\hline AKAR & 1.000 & & & & & & \\
LAKT & 0.104 & 1.000 & & & & & \\
KALD & -0.434 & -0.134 & 1.000 & & & & \\
LIKID & 0.350 & -0.140 & -0.529 & 1.000 & & & \\
HASP & -0.529 & 0.331 & 0.131 & -0.298 & 1.000 & & \\
PAZP & 0.057 & 0.773 & -0.074 & -0.104 & 0.243 & 1.000 & \\
YAS & -0.179 & 0.417 & 0.050 & -0.237 & 0.255 & 0.342 & 1.000 \\
\hline \hline
\end{tabular}

Tablo 4'de korelasyon analizi sonuçları verilmiştir. Tabloya göre, HASP ile AKAR değişkenleri arasıdaki korelasyon katsayıSı -0.53 iken LIKID ile KALD arasında da benzer bir ilişki mevcuttur. PAZP ile LAKT arasındaki korelasyon kaysayıSı +0.77 iken YAS ile LAKT arasındaki ilişkinin şiddeti ise +0.41 'dir. Bu değişkenler arasındaki korelasyon katsayıları \%99 güvenilirlik düzeyinde anlamlı çıkmıştır. Korelasyon matrisinden görüleceği üzere, değişkenler arasında tahmin edicilerimizi sıkıntıya sokacak düzeyde, +/0.90'dan yüksek bir ilişki bulunmamaktadır.

Panel veri analizinde temel olarak iki farklı modelden birisi kullanılarak tahmin yapılmaktadır. Bunlardan birincisi, sabit etkiler modeli (fixed effects model); ikincisi, tesadüfi etkiler modelidir (random effects model). Sabit etkiler modelinde, sigorta şirketlerinin bireysel etkileri sabit bir terim ile ifade edilmektedir. Tesadüfi etkiler modelinde ise sigorta şirketlerinin bireysel etkileri tesadüfi olarak kabul edilmektedir (Greene, 2003:285). Bu iki modelden, hangisinin tercih edileceği konusunda kesin bir kural bulunmamakla birlikte, kullanılan örneklemin kaynağı incelenerek tahmin yapmak mümkündür. Eğer araştırmada kullanılan örneklem, daha büyük bir ana kütleden tesadüfî örnekleme yoluyla seçilmişse, tesadüfî etkiler modeli daha uygun olacaktır. Tersine, araştırmanın konusu sadece elde bulunan örneklemin incelenmesinden ibaretse sabit etkiler modeli daha uygun olacaktır (Hsiao, 2003:43).

Yukarıda belirtilen basit kestirim kuralları bazı durumlarda faydalı olmakla birlikte, bu çalışmada kullanılan verinin niteliği hakkında kesin bir yargıya varmak kolay değildir. Bu belirsizliği ortadan kaldırmak için istatistikî bir yöntemin kullanılması zorunlu olmaktadır. Bu yöntem, Hausman testidir. Hausman testinde sıfır hipotezi, tesadüfî etkiler modelinin etkin olduğunu; alternatif hipotez ise, tesadüfî etkiler modelinin etkin olmadığını ifade etmektedir. Diğer bir ifadeyle, Hausman testi, tesadüfî etkiler modelinin etkinliğinin sınanmasına yöneliktir (Hausman, 1978:1267-1268).

Çalışmamızda Türkiye'de faaliyet gösteren hayat dışı sigorta alanında faaliyet gösteren 15 şirket tesadüfi olarak değil prim üretiminde en fazla pazar payına sahip şirketler alınarak dar kapsamlı ve özellikli şirketlere ait veri seti kullanılmıştır. Hausman test istatistiklerinin sonucunda elde edilen $\% 5$ 'in altındaki bir olasılık değeri, tesadüfi etkiler modelinin uygun olmadığı ve sabit etkiler modelinin tercih edilmesi gerektiği anlamına gelmektedir.

Tablo 5: Hausman Testi Sonuçları

İlişkili Tesadüfi Etkiler Hausman Testi

Yatay Kesit Tesadüfi Etkiler Testi

\begin{tabular}{|l|c|c|}
\hline Test Özeti & $\chi^{2}$ Test İstatistiği & Anlamlılık $(p)$ \\
\hline Yatay Kesit Tesadüfi & 28.09 & 0.0001 \\
\hline
\end{tabular}

Tablo 5'de gösterildiği gibi $\mathrm{p}=0.0001<0.05$ olduğu için $\mathrm{H}_{0}$ hipotezi red edilmiş sabit etkiler modelinin kullanıımasının uygun olduğu yönünde bulgulara ulaşılmıştır. Bu nedenle analizde sabit etkiler modeli kullanılmıştır. 
Model seçiminden sonra sabit etkiler modelinde otokorelasyon ve değişen varyans sorunu olup olmadığı incelenmelidir. Panel regresyon analizlerinin dayandığı temel varsayımlardan biri de farklı gözlemler için aynı hatalar arasında ilişki (korelasyon) olmamasıdır. Eğer hata terimleri arasında bir korelasyon ilişkisi varsa bu durum otokorelasyon ya da seri korelasyon olarak isimlendirilir. Veri setinde otokorelasyonun olup olmadığı Wooldridge otokorelasyon testi ile araştırımış ve $F$ istatistiği ve olasılık değerlerinin $F(1,14)=$ 109.515 (Prob > F =0.0000) olduğu tespit edilmiştir. Buradan hareketle, Wooldridge otokorelasyon test istatistiği sonucuna göre, modelde "otokorelasyon yoktur" şeklinde kurulan boş hipotez reddedilmiştir. Başka bir ifadeyle, modeldeki hata terimleri arasında otokorelasyon problemi gözlemlenmiştir.

Sabit etkiler modelinde birimlere göre değişen varyans ve otokorelasyon sorunu olup olmadığının tespit edilmesi gerekmektedir. Bu amaçla Düzenlenmiş Wald testi ile aşağıdaki hipotez kurulmuştur.

$\mathrm{H}_{0}=$ Birimlere göre değişen varyans yoktur.

$\mathrm{H}_{1}=$ Birimlere göre değişen varyans vardır.

Düzenlenmiş Wald testi sonucu ve olasılık değeri $\chi^{2}(19)=5013.10$ ve (Prob $>\chi^{2}=0.0000$ ) olarak hesaplanmıştır. Bu test sonucuna göre "birimlere göre değişen varyans yoktur" boş hipotez red edilmiş ve böylece değişen varyans probleminin geçerli olduğu sonucuna ulaşılmıştır.

Regresyon modelinde var olan hem birinci dereceden oto korelasyon ve hem de değişen varyans problemlerini düzeltmek için, Beck ve Katz (1995) tarafından geliştirilen GSL Period SUR (PCSE) yöntemi ile sabit etkili panel veri regresyon modeli tahmin edilmiş ve Tablo 6'daki sonuçlara ulaşılmıştır.

Tablo 6: Sabit Etkili Panel Veri Regresyon Tahmin Sonuçları

\begin{tabular}{crrrr}
\hline \hline Değişken & \multicolumn{1}{c}{ Katsayı } & Standart Hata & \multicolumn{1}{c}{$t$-ist. } & $p$ \\
\hline \hline C & -0.997801 & 0.053689 & -18.59 & 0.0000 \\
LAKT & 0.062034 & 0.003753 & 16.53 & 0.0000 \\
KALD & -0.014818 & 0.000951 & -15.58 & 0.0000 \\
LIKID & 0.048039 & 0.005446 & 8.82 & 0.0000 \\
HASP & -0.076450 & 0.006430 & -11.89 & 0.0000 \\
PAZP & 0.001686 & 0.000669 & 2.52 & 0.0122 \\
YAS & -0.004090 & 0.000730 & -5.61 & 0.0000 \\
\hline \hline
\end{tabular}

Ağırlıklandırılmış İstatistikler

\begin{tabular}{ll}
\hline \hline $\mathrm{R}^{2}$ & 0.827990 \\
Düzeltilmiş $\mathrm{R}^{2}$ & 0.817372 \\
Tahminin Std. Hatası & 1.019909 \\
F-istatistiği & 77.98059 \\
Anlamlılık & 0.000000 \\
DW İst. & 1.701084 \\
\hline \hline
\end{tabular}

Ağırlıklandırılmamış İstatistikler

\begin{tabular}{ll}
\hline \hline $\mathrm{R}^{2}$ & 0.599405 \\
Hata Ter. Kareleri Top. & 0.473847 \\
DW İst. & 1.181939 \\
\hline \hline
\end{tabular}

Tablo 6'daki bağımsız değişkenlere ait katsayılar kullanılarak, Türkiye'de hayat dışı sigortacııık sektöründe faaliyet gösteren şirketlerin aktif karlıı̆ının eşitlik şeklinde ifadesi ise aşağıdaki gibi olacaktır:

$$
A K A R=-0.998+0.062 L A K T-0.015 K A L D+0.048 L I K I D-0.077 H A S P+0.002 P A Z P-0.004 Y A S
$$

Tablo 6'daki bütün katsayılar anlamlı olmakla birlikte, her bir değişkenin aktif karlılığıyla olan ilişkisini literatürle uyumluluğunu araştırmak gerekmektedir. Literatürde Kaya ve Kaya (2015) çalışması ve Mwangi 
ve Murigu (2015) çalışmaları ile uyumlu olarak LAKT değişkeni ile aktif kârılığı arasında \%1 anlam düzeyinde pozitif ve anlamlı bir ilişki vardır. Başka bir ifadeyle, LAKT değişkeni ortalama \%10 arttığında aktif kârııı̆ı \% 0.6 oranında artmaktadır.

Chen vd. (2009), Malik (2011), Tornyeva (2013), Doğan (2013), Çekrezi (2015) çalışmalarıyla tutarlı olarak KALD değişkeni ile aktif kârlıı̆ı̆ arasında \%1 anlam düzeyinde negatif ve anlamlı bir ilişki olduğu yönünde bulgulara ulaşılmıştır. Tahmin edilen regresyon modelindeki KALD değişkenin katsayısının yaklaşık -\%1.48 olması, sigorta şirketlerinin borçlanma oranlarını \%10 arttırmaları halinde aktif kârıııklarının \%1.48 oranında azalacağı anlamına gelmektedir.

Boadi, Antwi ve Lartey (2013) çalışmasıyla uyumlu olarak LIKID değişkeni ile aktif kârııı̆ı arasında \%1 anlam düzeyinde pozitif ilişki vardır. Bu nedenle LIKID ile Aktif kârıı̆̆ı arasında negatif ilişki olduğuna dair $\mathrm{H}_{1}$ hipotezi red edilmiştir. LIKID (cari oran) değişkeni ortalama \%10 arttığında aktif kârlıı̆ı ortalama \%4.8 oranında artacaktır.

Malik (2011), Doğan (2013) çalışmalarıyla tutarlı bir şekilde HASP değişkeni ile aktif kârııı̆̆ arasında \%1 anlam düzeyinde negatif ilişki bulunmaktadır. HASP ile aktif kârlıı̆̆ arasında negatif ilişki olduğu yönündeki $\mathrm{H}_{2}$ hipotezi kabul edilmiştir. HASP oranı ortalama \%10 artıığında aktif kârııı̆ı \%7.65 oranında azalmaktadır.

PAZP değişkeni ile aktif kârlıı̆ı arasında, \%5 anlam düzeyinde, beklenildiği üzere pozitif ve anlamlı bir ilişki tespit edilmiş olup "H3: Türkiye'de hayat dışı sigorta sektöründe en fazla pazar payına sahip 15 şirketin pazar payı ile kârıııkları arasında pozitif bir ilişki vardır” hipotezi kabul edilmiştir. PAZP değişkeninde meydana gelecek \%10'luk artış/azalış aktif karlıı̆ını ortalama \%1.69 oranında artıracak/azaltacaktır.

YAS değişkeni ile aktif kârlıı̆̆ arasında \%1 anlam düzeyinde negatif, anlamlı fakat zayıf bir ilişki olduğu sonucuna ulaşılmıştır. Bundan dolayı, YAS ile aktif kârlıı̆̆ı arasında pozitif ilişki olduğu yönündeki $\mathrm{H}_{4}$ hipotezi red edilmiştir. Sigorta şirketlerinin faaliyette bulundukları süreyi ifade eden YAS değişkeni \%10 arttığında aktif kârlıı̆ı \%0.41 oranında azalmaktadır. Bu sonuç, Pervan (2012), Kaya ve Kaya (2015) çalışmalarıyla uyumluluk göstermemektedir.

Ayrıca, 2010-2015 döneminde Türkiye'de hayat dışı sigortacılık sektörünün yoğunlaşma derecesi Herfindahl - Hirschman Endeksi (HHI) kullanılarak hesaplanmış ve sonuçlar Tablo 7'de gösterilmiştir.

Tablo 7: Türkiye'de Hayat Dışı Sigortacılık Sektörünün HHI Değerleri

\begin{tabular}{|c|c|c|c|c|c|c|}
\hline Yıllar & 2010 & 2011 & 2012 & 2013 & 2014 & 2015 \\
\hline HHI Değeri & 747.80 & 791.99 & 813.69 & 848.64 & 773.80 & 731.60 \\
\hline
\end{tabular}

Buna göre; analiz döneminin 2010-2013 yıllarını kapsayan ilk dört yıllık döneminde, HHI değeri 747.80'den 848.64 değerine ulaşarak bir yükseliş trendi sergilemiştir. 2014 yılında HHI değeri 773.80 iken 2015 yılında ise analiz dönemi boyunca en düşük değer olan 731.6 değerine düşmüştür (Tablo 7).

Bu sonuçlara göre, Türk hayat dışı sigortacılık sektörünün HHI Endeks değerleri 1.500'ün oldukça altında olduğu için yoğun olmayan bir piyasa görünümüne sahiptir. Bu nedenle Yapı-Davranış- Performans yaklaşımına ilişkin hipotezler dikkate alındığında, Türk hayat dışı sigorta sektörünün aktif kârııı̆ının yoğunlaşmadan değil faaliyetlerindeki etkinlikten kaynaklandığını ve sektörde rekabetçi bir yapının hakim olduğu sonucuna ulaşmak mümkündür. 


\section{Sonuç}

Bu çalışmada Türk hayat dışı sigorta sektöründe finansal performans üzerinde etkiye sahip olan firma içi faktörler ile performans arasındaki ilişkinin belirlenmesi ve mali performansın bir göstergesi olan aktif kârıı̆ı̆ının etkinlikten mi yoksa yoğunlaşmadan $\mathrm{mı}$ kaynaklandığı sorusuna cevap bulabilmek amaçlanmıştır. Bu amaçla, Türk sigorta sektöründe faaliyet gösteren 36 hayat dışı sigorta şirketi arasında 2015 yılı 10 aylık verilere göre toplam \%83.38 pazar payına sahip 15 sigorta şirketinin 2010-2015 yılı 3. çeyrek dönem dahil toplam 23 çeyrek dönem mali verileri ile performans ilişkisine yönelik panel veri analizi yapılmıştır. Bağımlı değişken olarak aktif kârııı̆ı, bağımsız değişken olarak aktif büyüklüğü, kaldıraç, hasar/prim, likidite, pazar payı, faaliyet süresi değişkenleri kullanılmıştır.

Çalışmaya dahil edilen 15 hayat dışı sigorta şirketinin 2010-2015 dönemine ait verileri kullanılarak yapılan panel regresyon sonuçlarına göre, aktif büyüklüğü, likidite ve pazar payı değişkenleri şirketlerin aktif karlılığı üzerinde pozitif ve istatistiki olarak anlamlı bir etkiye sahipken kaldıraç, hasar/prim oranı ve faaliyet süresi değişkenlerinin aktif karlıığı üzerindeki etkisi negatif ve istatistiki olarak anlamlıdır. Çalışmanın bir diğer sonucuna göre, $\mathrm{HHI}$ endeksi analiz dönemi boyunca 1500'ün altında olduğu için Türkiye'de hayat dışı sigortacılık sektörünün yoğun olmayan bir piyasa olduğu tespit edilmiştir.

Bu çalışmada hayat dışı sigorta firmalarının kârııı̆ııı etkileyen firmalara özgü faktörler incelenmiştir. Daha sonraki yapılacak çalışmalarda firma dışı faktörler de analize dahil edilebilir. Ayrıca sonraki çalışmalarda hayat dışı sigorta sektöründe yoğunlaşma olup olmadığı farklı ölçütler ve yöntemler kullanılarak araştırılabilir.

\section{Kaynakça}

Abbasoglu, O. F., Aysan, A. F., Günes, A. (2007). Concentration, competition, efficiency and profitability of the Turkish banking sector in the post-crises period. Banks and Bank Systems, 2(3), 106-115.

Akın, F., \& Ece, N. (2013). IMKB'de işlem gören sigorta şirketlerinin 2006-2010 dönemi finansal performanslarının analizi. Muhasebe ve Finansman Dergisi, (57), 89-106.

Almajali, A. Y., Alamro, S. A., \& Al-Soub, Y. Z. (2012). Factors affecting the financial performance of Jordanian insurance companies listed at Amman Stock Exchange. Journal of Management Research, 4(2), 266-289. DOI: 10.5296/jmr.v4i2.1482

Bain, J. S. (1951). Relation of profit rate to industry concentration: American manufacturing, 1936-1940. The Quarterly Journal of Economics, 65(3), 293-324. DOI: 10.2307/1882217

Beck, N., \& Katz, J. N. (1995). What to do (and not to do) with time-series cross-section data. American Political Science Review, 89(3), 634-647. DOI: 10.2307/2082979

Berry-Stölzle, T. R., Weiss, M. A., \& Wende, S. (2011). Market structure, efficiency, and performance in the European property-liability insurance industry. In ARIA 2011 Meeting.

Boadi, E. K., Antwi, S., \& Lartey, V. C. (2013). Determinants of profitability of insurance firms in Ghana. International Journal of Business and Social Research, 3(3), 43-50.

Brooks, C. (2008). Introductory econometrics for finance. Cambridge University Press.

Calkins, S. (1983). The new merger guidelines and the Herfindahl-Hirschman Index. California Law Review, 71(2), 402-429. DOI: 10.15779/Z38B74S

Cekrezi, A. (2015). Determinants of financial performance of the insurance companies: A case of Albania. International Journal of Economics, Commerce and Management, 3(4), 1-10.

Chen, J. S., Chen, M. C., Liao, W. J., \& Chen, T. H. (2009). Influence of capital structure and operational risk on profitability of life insurance industry in Taiwan. Journal of Modelling in Management, 4(1), 7-18. DOI: 10.1108/17465660910943720 
Civelek, M. A., \& Al-Alami, M. W. (1991). An empirical investigation of the concentration-profitability relationship in the Jordanian banking system. Savings and Development, 15(3), 247-260.

Çekici, M. E., \& İnel, M. N. (2013). Türk sigorta sektörünün direkt prim üretimlerinin tahmin teknikleri ile incelenmesi. Marmara Üniversitesi İ̈B Dergisi, 34(1), 135-152.

Çelik, T., \& Kaplan, M. (2007). Türk sigortacılık sektöründe karlılık ve yoğunlaşma ilişkisi. Ankara Üniversitesi Siyasal Bilimler Fakültesi Dergisi, 62(04), 69-82. DOI: 10.1501/SBFder_0000002050

Demsetz, H. (1973). Industry structure, market rivalry, and public policy. The Journal of Law \& Economics, 16(1), 1-9. DOI: 10.1086/466752

Doğan, M. (2013). Sigorta firmalarının sermaye yapısı ile kârlılık arasındaki ilişki: Türk sermaye piyasası üzerine bir inceleme. Muhasebe ve Finansman Dergisi, 57. 121-136.

Elitaş, B. L., Doğan, M. (2013). Sermaye yapısını belirleyen faktörler: IMKB sigorta şirketleri üzerine bir araştırma. MÖDAV Muhasebe Bilim Dünyası Dergisi, 15(2), 41-57.

Goldberg, L. G., \& Rai, A. (1996). The structure-performance relationship for European banking. Journal of Banking \& Finance, 20(4), 745-771. DOI: 10.1016/0378-4266(95)00021-6

Greene, William H. (2003), Econometric Analysis (Fifth Edition), Prentice Hall, USA.

Gujarati, N. D., Porter, C. D. (2012). Temel Ekonometri. 5. Baskı, Literatür Yayınları, Çev. Ümit Şenesen \& Gülay Günlük Şenesen.

Günalp, B., \& Çelik T. (2004), Türk bankacılık sektöründe piyasa yapısı ve performans ilişkilerinin etkinlik için doğrudan bir ölçüt kullanılarak test edilmesi. Gazi Üniversitesi İktisadi ve İdari Bilimler Fakültesi Dergisi, 6(3), 31-57.

Hakimi, A., Hamdi, H., Djelassi M. (2015), Testing the concentration-performance relationship in the Tunisian banking sector. Journal of Economics and Business, 18(2), 41-62.

Hausman, J. A. (1978). Specification tests in econometrics. Econometrica: Journal of the Econometric Society, 1251-1271. DOI: 10.2307/1913827

Hausman, J. A., \& Sidak, J. G. (2007). Evaluating market power using competitive benchmark prices rather than the Hirschman-Herfindahl index. Antitrust Law Journal, 74(2), 387-407.

Hsiao, C. (2004), Analysis of Panel Data (Second Edition), Cambridge University Press, USA.

Kaya, E. Ö., \& Kaya, B. (2015). Türkiye'de hayat sigortası şirketlerinin finansal performansını belirleyen firmaya özgü faktörler: panel veri analizi. Finansal Araştırmalar ve Çalışmalar Dergisi, 7(12), 93111. DOI: $10.14784 /$ frs. 99196

Knutsen, S. (1999). Government regulations, information costs and concentration in the Norwegian insurance industry, 1960-1990. Scandinavian Economic History Review, 47(1), 65-83. DOI:10.1080/03585522.1999.10419805

Malik, H. (2011). Determinants of insurance companies profitability: An analysis of insurance sector of Pakistan. Academic Research International, 1(3), 315-321.

Mehari, D., \& Aemiro, T. (2013). Firm specific factors that determine insurance companies performance in Ethiopia. European Scientific Journal, 9(10), 245-255.

Mwangi, M., \& Murigu J. W. (2015). The determinants of financial performance in general insurance companıes in Kenya. European Scientific Journal, 11(1), 288-297.

Njegomir, V., \& Stojić, D. (2011). Liberalisation and market concentration impact on performance of the non-life insurance industry: The evidence from Eastern Europe. The Geneva Papers on Risk and Insurance Issues and Practice, 36(1), 94-106. DOI: 10.1057/gpp.2010.32 
Njegomir, V., Stojić, D., \& Marković, D. (2011). Liberalisation, market concentration and performance in the non-life insurance industry of Ex-Yugoslavia. Ekon. Misao Praksa Dbk., 20(1), 21-40.

Oscar Akotey, J., Sackey, F. G., Amoah, L., \& Frimpong Manso, R. (2013). The financial performance of life insurance companies in Ghana. The Journal of Risk Finance, 14(3), 286-302. DOI:10.1108/JRF-11-2012-0081

Özcan, A., \& Çiftçi, Ç. (2015), Türkiye'de mevduat bankacılığında yoğunlaşma ve kârlılık ilişkisi (2006-2013 dönemi). Niğde Üniversitesi İktisadi ve İdari Bilimler Fakültesi Dergisi, 8(3), 1-12.

Pervan, M., Curak, M., \& Mariajnovic, I. (2012). Dynamic panel analysis of B\&H insurance companies' profitability. Recent Researches in Business and Economics, 158-163.

Pope, N., \& Ma, Y.L. (2008), The market structure-performance relationship in the international insurance sector. The Journal of Risk and Insurance, 75(4), 947-966. DOI: 10.1111/j.15396975.2008.00292.x

Rahman, S., Kakakhel, S. J., \& Ikbal, K. (2014). Capital structure decision of insurance industry of Pakistan. Abasyn University Journal of Social Sciences, 7(2), 328-335.

Rekabet Kurumu (2014). Rekabet Terimleri Sözlüğü, 5. Baskı, İnternet Adresi http://www.rekabet.gov.tr, Erişim Tarihi: 23.11.2015

Roberts, T. (2014). When bigger is better: A critique of the Herfindahl-Hirschman Index's use to evaluate mergers in network industries. Pace L. Rev., 34, 894-946.

Shahiki Tash, M. N., Pahlavani M., \& Barghandan K. (2015). Evaluating the relationship between concentration indicators and profitability of banking industry in Iran. Çankırı Karatekin Üniversitesi İktisadi ve İdari Bilimler Fakültesi Dergisi, 5(2), 1-11. DOI: 10.18074/cnuiibf.223

Smirlock, M. (1985). Evidence on the (non) relationship between concentration and profitability in banking. Journal of Money, Credit and Banking, 17(1), 69-83. DOI: 10.2307/1992507

Şenel, S. A. (2006). Sigorta şirketlerinde mali yeterlilik. Afyon Kocatepe Üniversitesi İktisadi ve İdari Bilimler Fakültesi Dergisi, 8(2), 297-315.

Tornyeva, K. (2013). Determinants of capital structure of insurance companies in Ghana. Research Journal of Finance and Accounting, 4(13), 52-60.

Wooldridge, J. M. (2010). Econometric analysis of cross section and panel data. MIT press. 